\title{
Porównawcza ocena tolerancji i skuteczności czterech schematów pooperacyjnej radioterapii chorych na glejaki wielopostaciowe
}

\author{
Grzegorz Głowacki
}

Wstęp. Wyniki leczenia chorych z rozpoznaniem GBM są złe, z czym wiąże się niepomyślne rokowanie. Podstawą leczenia radykalnego jest zabieg operacyjny w skojarzeniu z radiochemioterapią. Nie w każdym jednak przypadku możliwe jest zastosowanie leczenia skojarzonego, a ze względu na zły stan ogólny chorych lub stopień zaawansowania procesu nowotworowego często jedynym postępowaniem pozostaje leczenie paliatywne lub objawowe.

Jedną z metod postępowania paliatywnego może być zastosowanie radioterapii stereotaktycznej, której rola w tej grupie chorych nie jest dokładnie określona. Prawdopodobnie u wybranych chorych podwyższenie dawki całkowitej przy pomocy boostu stereotaktycznego może wiązać się z korzystnym wpływem na efekt leczenia.

Cel. Celem pracy jest określenie czynników prognostycznych oraz ocena skuteczności i tolerancji czterech schematów frakcjonowania dawki promieniowania u chorych na glejaki wielopostaciowe mózgu.

Materiał. Przedmiotem analizy jest grupa 227 chorych (132 mężczyzn i 95 kobiet) w wieku od 20 do 80 lat leczonych z powodu glejaka wielopostaciowego. Chorych, w zależności od stanu ogólnego i radykalności przeprowadzonego leczenia chirurgicznego, kwalifikowano do czterech schematów radioterapii.

Metoda. Ocenę długości przeżycia przeprowadzono w oparciu o model Kaplana-Meiera i test log-rank, posługując się parametrem poziomu istotności statystycznej $p$-value. Analizę wieloczynnikową przeprowadzono w oparciu o nieparametryczny model proporcjonalnego ryzyka Coxa.

Wyniki. W analizie jednoczynnikowej wykazano, iż czynnikami znamiennie statystycznie wpływającymi na długość przeżycia są stan ogólny chorych $(p=0,0001)$, stopień sprawności neurologicznej $(p=0,00002)$, wiek $(p=0,005)$, objętość guza w przedoperacyjnych badaniach obrazowych $(p=0,004)$, stopień miejscowego zaawansowania $(p=0,02)$, doszczętność zabiegu operacyjnego $(p=0,01)$, schemat radioterapii $(p=0,00001)$ oraz zastosowanie leczenia ratującego ( $p=0,0001)$. Stopień sprawności neurologicznej jest czynnikiem silnie skorelowanym ze stanem ogólnym $(p=0,0001)$.

W analizie Coxa wykazano, iż stan ogólny, operacyjne zmniejszenie masy guza, jego objętość przed zabiegiem operacyjnym, stopień miejscowego zaawansowania (w tym wieloogniskowość) oraz zastosowanie leczenia ratującego (głównie radiochirurgii) są niezależnymi od siebie czynnikami prognostycznymi przeżycia. Toksyczność wczesna leczenia jest niewielka, a występujące objawy są dobrze kontrolowane farmakologicznie.

Wnioski.

- Wiek poniżej 40 lat, dobry stan ogólny (Zubrod 0-2), pojedynczy guz o objętości do $30 \mathrm{~cm}^{3}$, zastosowanie cytoredukcyjnej operacji są niezależnymi pozytywnymi czynnikami prognostycznymi przeżycia.

- Zastosowanie boostu radiochirurgicznego jako elementu pierwotnego leczenia w radioterapii paliatywnej lub jako leczenia kolejnego rzutu u chorych w dobrym stanie ogólnym i z guzami o małych objętościach pozwala na wydłużenie przeżyć całkowitych w porównaniu z chorymi, u których stosowano inny rodzaj leczenia ratującego lub nie stosowano go wcale.

- Dobra i akceptowalna tolerancja leczenia porównywalna dla każdego z zastosowanych schematów radioterapii. 


\section{Comparative evaluation of tolerability and efficacy of four schedules of post-operative radiotherapy in patients with glioblastoma multiforme}

Background. The results of GBM patients' treatment are poor and prognosis is unfavourable. Nowadays the primary treatment consists of radical surgery and adjuvant radiochemotherapy. There are a great number of prognostic factors for survival and in some cases, due to poor condition of the patient or an extension of the tumour, a palliative or symptomatic treatment remains the only approach.

Stereotactic radiotherapy could be an option in palliative treatment, although it role in GBM patients is still not well defined. Probably in some patients, an increase of total dose with the use of a stereotactic boost may be a potential treatment option worth consideration.

Aim. The aim of the study was to provide a specification of the overall survival prognostic factors and evaluation of the efficacy and tolerance of four schedules of radiotherapy.

Material. The analysed group consisted of 227 GBM patients aged from 20 to 80 ( 132 men, 95 women). Depending on the performance status and extension of the surgery all patients were qualified for one of four radiotherapy schedules. Methods. A Kaplan-Meier actuarial calculation and log-rank test were performed to evaluate the overall survival. The differences between groups were considered to be statistically significant if the $p$-value was less than 0.05 . The Cox proportional hazard regression model was used to define independent prognostic factors of survival.

Results. Univariate analysis showed that performance status $(p=0.0001)$, neurological condition $(p=0.00002)$, age $(p=0.005)$, tumour volume $(p=0.004)$, tumour stage $(p=0.02)$, neurosurgery $(p=0.01)$, treatment schedule $(p=0.00001)$ and salvage treatment $(p=0.0001)$ significantly influenced the overall survival. Neurological condition was highly correlated with performance status $(p=0.0001)$.

The multivariative Cox regression model revealed that the following variables independently influenced overall survival: performance status, neurosurgery, preoperative tumour volume, multifocal disease, salvage treatment (mainly radiosurgery). The toxicity of radiotherapy was low and in general well tolerated.

\section{Conclusions.}

- Age below 40 years, good performance status (Zubrod 0-2), single tumour, volume of the tumour (up to $30 \mathrm{~cm}^{3}$ ) and cytoreductive surgery are statistically significant and independent positive prognostic factors of overall survival.

- The additional radiosurgical boost as a component of primary palliative treatment or as a secondary treatment at patients with good performance status and small residual tumours allows prolongation of the overall survival in comparison to the groups of patients with other salvage (but without SRS) or without any salvage therapy.

- The tolerance of treatment is good and acceptable and comparable in all radiotherapy schedules used.

NOWOTWORY J Oncol 2016; 66, 3: 193-201

Słowa kluczowe: glejak wielopostaciowy, radioterapia, radiochirurgia

Key words: glioblastoma multiforme (GBM), radiotherapy, radiosurgery

\section{Wstęp}

Pierwotne nowotwory mózgu stanowią około $2 \%$ wszystkich nowotworów złośliwych u dorosłych. Około połowa z nich to wywodzące się z komórek neuroepitelium glejaki, z których najczęstsze to glejaki wielopostaciowe (GBM - glioblastoma multiforme). Stanowią one około 20\% wszystkich pierwotnych guzów mózgu u dorosłych i około 75\% wszystkich glejaków niskozróżnicowanych.

Ze względu na szybki wzrost tych guzów oraz ich oporność na zastosowane leczenie nowotwory te charakteryzują się najcięższym przebiegiem klinicznym, prowadząc w krótkim czasie do zgonu. Wyniki leczenia chorych z rozpoznaniem GBM są złe, z czym wiąże się niepomyślne rokowanie.

Mediany czasów przeżyć wynoszą ok. 3-5 miesięcy po zastosowaniu leczenia neurochirurgicznego, ok. 6 miesięcy pośród chorych napromienianych paliatywnie po operacji oraz ok. 9-12 miesięcy po zastosowaniu pooperacyjnej konwencjonalnej radioterapii.

Do około 2005 roku podstawą leczenia radykalnego był zabieg operacyjny uzupełniony napromienianiem loży guza. Obecnie standardem leczenia uzupełniającego jest skojarzona radiochemioterapia.

Nie w każdym jednak przypadku możliwe jest zastosowanie leczenia skojarzonego, a w wielu, z uwagi na zły stan ogólny chorych lub stopień zaawansowania procesu nowotworowego, jedynym leczeniem pozostaje leczenie paliatywne lub objawowe. Dodatkowo opisano wiele czynników prognostycznych wpływających na efekt leczenia, pośród których do najczęściej wymienianych należą wiek chorych, stan ogólny i doszczętność leczenia operacyjnego. 
Jedną z metod postępowania paliatywnego może być zastosowanie radioterapii stereotaktycznej, której rola w tej grupie chorych nie jest dokładnie określona. Prawdopodobnie u wybranych chorych podwyższenie dawki całkowitej przy pomocy boostu stereotaktycznego może wiązać się z korzystnym wpływem na efekt leczenia.

\section{Cel}

Celem pracy jest określenie czynników prognostycznych oraz ocena skuteczności i tolerancji czterech schematów frakcjonowania dawki promieniowania u chorych na glejaki wielopostaciowe mózgu.

\section{Materiał}

Przedmiotem retrospektywnej analizy była grupa 227 chorych (132 mężczyzn i 95 kobiet) w wieku od 20 do 80 lat leczonych z powodu glejaka wielopostaciowego w Centrum Onkologii — Instytucie im. Marii Skłodowskiej-Curie, Oddział w Gliwicach w latach 2000-2006. Chorych, w zależności od stanu ogólnego i radykalności przeprowadzonego leczenia chirurgicznego, kwalifikowano do czterech schematów radioterapii.

- Schemat 1 - konwencjonalna radioterapia loży guza z marginesem (60Gy/30 fr - 50 chorych).

- Schemat 2 - hipofrakcjonowane napromienianie całego mózgowia z dodatkowym boostem radiochirurgicznym na guz resztkowy (20Gy/5 fr + SRS -74 chorych).

- Schemat 3 - hipofrakcjonowane napromienianie loży i guza resztkowego z marginesem, $\mathrm{z}$ dodatkowym boostem radiochirurgicznym (28Gy/7 fr + SRS - 49 chorych).

- Schemat 4 - hipofrakcjonowana radioterapia całego mózgowia (20Gy/5fr - 54 chorych).

\section{Metoda}

Ocenę długości przeżycia przeprowadzono w oparciu o model Kaplana-Meiera oraz test log-rank, posługując się parametrem poziomu istotności statystycznej $p$-value (ryc. 1).

Analizę wieloczynnikową przeprowadzono w oparciu o nieparametryczny model proporcjonalnego ryzyka Coxa.

Ocenę tolerancji leczenia dokonano w oparciu o poniższe kryteria:

- Tolerancja bardzo dobra - leczenie bez zaznaczonych komplikacji.

- Tolerancja dobra - okresowe dolegliwości wynikające z podwyższonego ciśnienia wewnątrzczaszkowego, kontrolowane farmakologicznie i niepowodujące przerwy w leczeniu.

- Tolerancja zła - pogorszenie stanu zdrowia i występowanie objawów powodujących przerwę w leczeniu bądź jego wcześniejsze zakończenie [1].

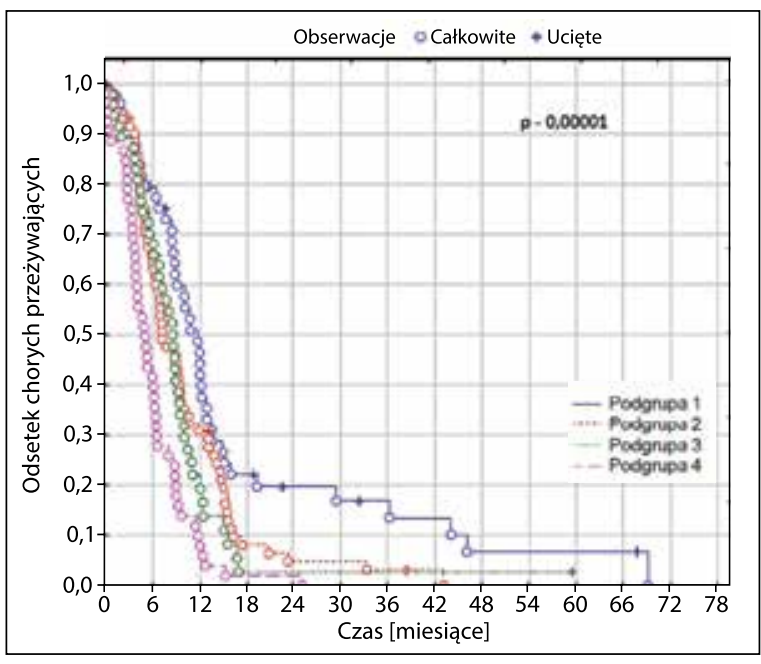

Rycina 1. Porównanie krzywych przeżycia w oparciu o model Kaplana-Meiera w czterech podgrupach ze względu na zastosowany schemat radioterapii

\section{Wyniki}

W analizie jednoczynnikowej wykazano, iż czynnikami znamiennie statystycznie wpływającymi na długość przeżycia są stan ogólny chorych $(p=0,0001)$, stopień sprawności neurologicznej $(p=0,00002)$, wiek $(p=0,005)$, objętość guza w przedoperacyjnych badaniach obrazowych $(p=0,004)$, stopień miejscowego zaawansowania $(p=0,02)$, doszczętność zabiegu operacyjnego ( $p=0,01)$, schemat radioterapii ( $p=0,00001$ ) oraz zastosowanie leczenia ratującego $(p=0,0001)$. Stopień sprawności neurologicznej jest czynnikiem silnie skorelowanym ze stanem ogólnym $(p=0,0001)$.

Nie zaobserwowano istotnego wpływu na przeżycia całkowite takich parametrów jak: długość trwania objawów przed rozpoczęciem leczenia, współistnienie chorób dodatkowych, stosowanie używek, stężenie hemoglobiny w surowicy krwi przed rozpoczęciem radioterapii, czas pomiędzy leczeniem operacyjnym a rozpoczęciem radioterapii czy lokalizacja guza.

W analizie Coxa wykazano, że stan ogólny, operacyjne zmniejszenie masy guza, jego objętość, stopień miejscowego zaawansowania (w tym wieloogniskowość) i zastosowanie leczenia ratującego (głównie radiochirurgii) są niezależnymi od siebie czynnikami prognostycznymi przeżycia.

Toksyczność wczesna leczenia jest niewielka, a występujące objawy są dobrze kontrolowane farmakologicznie. Bardzo dobra tolerancja dotyczyła 78,5\%, dobra 17,5\%, a zła jedynie $4 \%$ chorych.

\section{Dyskusja Czynniki zależne od chorego Wiek}

Wiek jest jednym z najczęściej opisywanych czynników prognostycznych przeżycia u chorych na glejaki wielopo- 
staciowe [2-7]. Względne ryzyko zgonu rośnie u chorych starszych. Znamiennie dłuższe mediany czasów przeżycia obserwuje się u chorych poniżej 40 roku życia [3].

W opublikowanym przez Currana i wsp. materiale [2] chorych na niskozróżnicowane glejaki podzielono na sześć grup prognostycznych, uwzględniając różne czynniki, w tym wiek, który istotnie wpływał na wyniki leczenia i rokowanie u chorych (u chorych powyżej 50 roku życia dochodzi do zmniejszenia median czasów przeżycia).

W analizowanym materiale własnym potwierdzono, że wiek chorych na glejaki wielopostaciowe w istotny sposób wpływa na wydłużenie czasów przeżycia.

\section{Stan ogólny}

Stan ogólny chorych jest jednym z najważniejszych czynników prognostycznych przeżycia, wpływającym znamiennie na wyniki leczenia chorych na glejaki wielopostaciowe, co zostało potwierdzone $w$ wielu badaniach i jest opisywane w piśmiennictwie $[2,4,7,8]$.

W opisywanym materiale własnym wykazano szczególny wpływ stanu ogólnego chorych przed rozpoczęciem leczenia promieniami na długość przeżycia. Czynnik ten statystycznie znamiennie wpływał na przeżycia zarówno w analizie jednoczynnikowej ( $p=0,0001)$, jak i po uwzględnieniu innych czynników w oparciu o model Coxa. Ryzyko względne zgonu rosło wraz z pogorszeniem stanu ogólnego chorych i było statystycznie znamiennie różne dla wszystkich pięciu podgrup (Zubrod $0-4)(p \leq 0,01)$.

Wykazano również, iż stan ogólny chorych korelował w sposób liniowy ze stanem neurologicznym, co potwierdza często opisywaną w piśmiennictwie tezę, iż czynnik ten może być również uważany za czynnik prognostyczny przeżycia.

\section{Długość trwania objawów}

Długość trwania objawów w opisanym materiale nie wpływała statystycznie znamiennie na czasy przeżycia $w$ badanej grupie chorych $(p=0,3)$. Analizowana grupa miała pod tym względem homogenny rozkład, ponieważ pomimo że czas ten znajdował się w szerokim przedziale, to większość chorych $(71,8 \%)$ zgłosiła się do Instytutu Onkologii w czasie nieprzekraczającym trzech miesięcy od wystąpienia pierwszego objawu choroby. Znaczenie tego czynnika jest trudne do określenia. Wątpliwości budzi przede wszystkim subiektywna ocena opisywanych objawów oraz czasu ich występowania przez samego chorego. U 44\% chorych pierwszym objawem był ból głowy, którego przyczyny jednak nie można jednoznacznie wiązać jedynie z guzem mózgu.

\section{Choroby wspótistniejące i używki}

Choroby układu krążenia są główną przyczyną zgonów w Polsce. Do najczęściej wymienianych należy choroba nie- dokrwienna mięśnia sercowego, choroby naczyń mózgu oraz nadciśnienie tętnicze. Choroby nowotworowe stanowią natomiast drugą w kolejności przyczynę zgonów, a z uwagi na wydłużanie się długości życia ich udział z roku na rok jest coraz większy. Picie alkoholu oraz palenie papierosów zwiększa ryzyko zapadalności zarówno na choroby układu krążenia, jak również na nowotwory złośliwe.

W analizowanej grupie $58 \%$ chorych stosowało używki, a u $41 \%$ chorych współwystępowały inne choroby, z których większość stanowiły schorzenia internistyczne.

Brak wpływu na mediany czasów przeżycia chorób dodatkowych oraz stosowania używek nie jest jednak zaskakujący, biorąc pod uwagę fakt, iż mediany czasów przeżycia chorych na glejaki wielopostaciowe wynoszą około jednego roku, a zasadniczą przyczyną zgonów u tych chorych jest nowotwór.W przypadku chorób nowotworowych o dobrym rokowaniu i bardzo długich czasach obserwacji schorzenia dodatkowe stanowią zapewne istotny przyczynek do umieralności chorych, jednak w przypadku chorych na glejaki wielopostaciowe wpływ ten jest wątpliwy.

W dużych badaniach populacyjnych przeprowadzonych wStanach Zjednoczonych nie wykazano jednoznacznie wpływu palenia papierosów na zapadalność na glejaki mózgu [9].

\section{Stężenie hemoglobiny}

Stężenie hemoglobiny przed rozpoczęciem radioterapii pozostawało bez znamiennego wpływu na przeżycia całkowite $(p=0,8)$. Prawdopodobnie jest to związane z kryterium kwalifikacji do leczenia. Chorzy w bardzo złym stanie ogólnym i głęboką anemią nie byli kwalifikowani do radioterapii przed wyrównaniem parametrów morfologii krwi, w związku z tym jedynie u sześciu chorych $(2,5 \%)$ poddanych radioterapii stężenie hemoglobiny przed rozpoczęciem radioterapii było mniejsze od $10 \mathrm{~g} \%$. Porównując czasy przeżycia u chorych ze stężeniem hemoglobiny poniżej i powyżej tej wartości, również nie uzyskano znamiennej różnicy. Stan kliniczny chorych z anemią niewielkiego stopnia nie korelował ze stężeniem hemoglobiny w surowicy krwi.

Nieliczne dane dotyczące wpływu stężenia hemoglobiny na czasy przeżycia są sprzeczne i mają charakter retrospektywnych analiz przeprowadzonych na małych grupach chorych. W retrospektywnej analizie obejmującej stu chorych napromienianych po operacji lub biopsji wykazano znamienny wpływ stężenia hemoglobiny na długość przeżycia. Mediany czasów przeżycia u chorych, z oznaczonym poziomem hemoglobiny mniejszym od $12 \mathrm{~g} \%$ wynosiły 7,9 w porównaniu z chorymi o wartościach tego parametru wyższych aniżeli $12 \mathrm{~g} \%$ (mediana $12,1, \mathrm{p}=0,002$ ), jednak po uwzględnieniu w analizie innych czynników nie wykazano znamiennej różnicy pomiędzy opisywanymi grupami [10]. W kolejnym badaniu wykazano, iż wzrastający poziom hemoglobiny wpływa na efekt leczenia i może być rozpatrywany jako czynnik prognostyczny przeżycia [11]. 


\section{Czynniki zależne od guza}

Umiejscowienie guza

Niektóre doniesienia sugerują, że umiejscowienie guza w płacie czołowym jest czynnikiem znamiennie wpływającym na lepsze wyniki leczenia chorych [7, 12-14]. Wpływ lokalizacji guza jako pojedynczego czynnika na przeżycia wydaje się jednak dyskusyjny. Bardziej prawdopodobny jest związek lokalizacji guza w płacie czołowym z możliwością przeprowadzenia rozleglejszego zabiegu operacyjnego czy zastosowania wyższych dawek promieniowania ze względu na stosunki anatomiczne i umiejscowienie względem struktur krytycznych oraz poza obszarami elokwentnymi mózgu.

Chorzy z rozpoznanym procesem wieloogniskowym rokowali gorzej aniżeli chorzy z pojedynczym guzem, nawet po włączeniu do analizy czynników takich jak schemat radioterapii czy rodzaj przeprowadzonego zabiegu operacyjnego. Biorąc pod uwagę kryteria kwalifikacji do radioterapii (w przypadku wieloogniskowości nie stosowano radioterapii konwencjonalnej - schemat 1) oraz brak możliwości przeprowadzenia radykalnej makroskopowo operacji lub ograniczenie zabiegu jedynie do biopsji, uzasadnione było przypuszczenie, że te czynniki mogły w znaczący sposób wpłynąć na wyniki leczenia.

\section{Objętość guza}

W analizowanej grupie chorzy z guzami o mniejszych objętościach w przedoperacyjnych badaniach obrazowych charakteryzowali się statystycznie znamiennie $(p=0,004)$ większymi medianami czasów przeżycia aniżeli chorzy z guzami o objętościach większych (mediany odpowiednio 9,2 i 6,6). Wyniki te potwierdzono również $w$ analizie wieloczynnikowej. W grupie chorych z guzami o większych objętościach odnotowano dwukrotnie większe ryzyko względne zgonu aniżeli u chorych z guzami o objętościach mniejszych $(p=0,001)$. Doniesienia w literaturze potwierdzają powyższe wyniki [5, 15-17].

Objętość guza w przedoperacyjnych badaniach obrazowych istotnie wpływała na wyniki leczenia, a po przeprowadzeniu analizy Coxa wykazano, iż wpływ ten jest niezależny od pozostałych czynników.

\section{Czynniki zależne od leczenia}

Leczenie operacyjne

Rola neurochirurgii w leczeniu chorych z guzami mózgu pozostaje niekwestionowana, będąc podstawą terapii chorych z tym rozpoznaniem. W przypadku jednak chorych na niskozróżnicowane glejaki rozległość przeprowadzanego zabiegu pozostaje przedmiotem dyskusji.

W przypadku chorych z guzami nieoperacyjnymi wykonywana jest jedynie biopsja stereotaktyczna. Takie postępowanie jest związane z gorszym rokowaniem. Mediany czasów przeżycia u chorych leczonych objawowo po wykonanej biopsji wynoszą około 3 miesiące [18].
W retrospektywnym badaniu obejmującym 86 chorych na glejaki wielopostaciowe wykazano statystycznie znamiennie dłuższe czasy przeżycia pomiędzy chorymi operowanymi a chorymi, u których wykonano jedynie biopsję (mediana odpowiednio 56 vs 29 tygodni, odsetki przeżyć rocznych i dwuletnich $62 \%$ i $23 \%$ vs $16 \%$ i $0 \%, p=0,00001$ ). Wyniki te potwierdzono również w analizie wieloczynnikowej [13].

Związek pomiędzy rozległością zabiegu operacyjnego a czasem do progresji choroby, czasem przeżycia całkowitego oraz jakością życia przedstawiono na podstawie retrospektywnego badania w grupie 105 chorych na glejaki wielopostaciowe poddanych biopsji lub operacji, a następnie leczeniu uzupełniającemu. Nie uzyskano statystycznie znamiennej różnicy w jakości życia bez względu na rodzaj wykonanego zabiegu operacyjnego, natomiast czas do progresji oraz mediany czasów przeżycia były znamiennie dłuższe u chorych operowanych radykalnie w porównaniu z chorymi po resekcji subtotalnej lub biopsji (PFS - progression free survival - czas do progresji - 10,3 vs 5,2 vs 3,6, OS - 20 vs 14,2 vs 8,3 miesiąca) [19].

Wykonanie kraniatomii i resekcji guza zmniejsza efekt masy, przyczyniając się do zmniejszenia objawów związanych z występowaniem podwyższonego ciśnienia śródczaszkowego, powoduje zmniejszenie liczby komórek nowotworowych, zwiększając skuteczność terapii adiuwantowych.

W wielu badaniach potwierdzono statystycznie znamienny wpływ rozległości zabiegu operacyjnego na przeżycia całkowite, jednakże większość badań ma charakter retrospektywny i obarczona jest błędem związanym z występowaniem innych czynników biologicznych, takich jak wiek czy stan ogólny chorych.

Radykalna resekcja w przypadku glejaków wielopostaciowych jest jednak praktycznie niemożliwa z uwagi na naciekający charakter tych guzów. Radykalność zabiegu jest także pojęciem względnym i uzależnionym od subiektywnej oceny operatora. Mając powyższe na względzie, w analizie własnej przyjęto jako kryterium radykalności zabiegu wynik pooperacyjnego badania obrazowego.

Dane dotyczące rozległości zabiegu operacyjnego są często sprzeczne. Część autorów uważa, że rozległość zabiegu operacyjnego pozostaje bez znamiennego wpływu na przeżycia u chorych na glejaki wielopostaciowe [20], jednak większość publikowanych danych sugeruje, iż rozległość zabiegu znamiennie wpływa na długość przeżycia u chorych na GBM. W części opisywanego materiału brano pod uwagę parametry wolumetryczne na podstawie wykonanych badań obrazowych, w innych opierano się na ocenie operatora [8, 19, 21-27].

Obecnie przyjętym standardem postępowania neurochirurgicznego w leczeniu chorych na glejaki wielopostaciowe jest maksymalna resekcja guza z akceptowalnym utrzymaniem funkcji neurologicznych, a w przypadku gu- 
zów nieoperacyjnych — wykonanie jedynie biopsji w celu pozyskania materiału do badania histopatologicznego.

Analizując wyniki w materiale własnym, wykazano w analizie jednoczynnikowej, iż radykalność zabiegu operacyjnego statystycznie znamiennie wpływa na wydłużenie median czasów przeżycia w porównaniu z chorymi operowanymi nieradykalnie $(p=0,03)$ i chorymi, u których wykonano jedynie biopsję $(p=0,01)$ (mediany odpowiednio 8,6 vs 6,4 vs 4,7$)$. Po uwzględnieniu innych czynników w analizie Coxa nie wykazano jednak istotnej różnicy pomiędzy chorymi operowanymi radykalnie i nieradykalnie ( $p=0,17, \mathrm{HR} 1,2)$. W związku z powyższym wykonano dodatkową analizę wieloczynnikową, w której porównano chorych operowanych z chorymi, u których wykonano jedynie biopsję stereotaktyczną. Wykazano istotną różnicę pomiędzy porównywanymi grupami $(p=0,02, H R 2,1)$.

\section{Schemat radioterapii}

Wydłużenie przeżyć całkowitych po zastosowaniu pooperacyjnej radioterapii zostało dowiedzione $\mathrm{w}$ wielu badaniach [28-31].

Obecnie stosowana dawka całkowita w radykalnej radioterapii chorych na glejaki wielopostaciowe została ustalona na podstawie badań opublikowanych w latach siedemdziesiątych m.in. przez Walkera, Salazara i Changa [32-34].

Ostatecznie korzyść po zastosowaniu dawki 60 Gy w porównaniu z chorymi, u których stosowano dawki całkowite $45 \mathrm{~Gy}$, potwierdzono w prospektywnym randomizowanym badaniu przeprowadzonym przez MRC BTWP (Medical Reserch Council Brain Tumour Working Party) [35].

W niektórych przypadkach, szczególnie u osób starszych, preferowana jest radioterapia hypofrakcjonowana z zastosowaniem niższych dawek całkowitych, stosowana z podobnym efektem [36-38].

Nie ma pewnych dowodów dotyczących korzyści ze stosowania dawek wyższych niż 60 Gy [39-46].

Zastosowanie radioterapii hiperfrakcjonowanej i przyśpieszonej nie przyniosło oczekiwanych rezultatów [43, 47-49].

Techniki radiochirurgiczne rozpatrywane są głównie jako element pierwotnego leczenia radykalnego w celu podwyższenia dawki całkowitej w guzie lub jako leczenie ratujące po niepowodzeniu leczenia pierwotnego. W pierwszym przypadku nie wykazano jednak korzyści z takiego postępowania [39,44], natomiast u chorych leczonych z powodu wznowy, na podstawie badań retrospektywnych, uzyskano mediany czasów przeżycia od zakończenia leczenia w przedziale od 7 do 10 miesięcy i czasów przeżycia od operacji rzędu 18-22 miesięcy. Należy jednak mieć na względzie wpływ preselekcji chorych do takiego leczenia [50-53].

Rola radioterapii paliatywnej z zastosowaniem nowoczesnych technik radiochirurgicznych w leczeniu glejaków wielopostaciowych nie jest natomiast określona.
Na podstawie opublikowanych w piśmiennictwie wyników badań można wnioskować, że istnieje zależność dawka — efekt w przedziale dawek pomiędzy 45 a 60 Gy. Wpływ na przeżycia przy podaniu dawek wyższych nie został potwierdzony w badaniach prospektywnych, stosowanie natomiast dawek niższych aniżeli 45 Gy traktowane jest jako leczenie paliatywne i nie jest rozpatrywane w badaniach klinicznych.

W materiale własnym uzyskano wyniki w leczeniu chorych z zastosowaniem konwencjonalnej radioterapii porównywalne do opisywanych w literaturze; mediana 10,4 (liczona od rozpoczęcia radioterapii - 11,7).

Zastosowanie radioterapii paliatywnej u chorych na GBM nieznacznie wydłuża przeżycia w porównaniu z chorymi leczonymi jedynie chirurgicznie i objawowo (mediany ok. 5-6 miesięcy) [54-56]. Krótkie schematy radioterapii preferowane są u chorych w złym stanie ogólnym, niekwalifikujących się do radioterapii konwencjonalnej oraz u chorych starszych.

W analizowanym materiale własnym przeżycia po zastosowaniu hypofrakcjonowanej radioterapii paliatywnej były zbliżone do publikowanych w piśmiennictwie i wynosiły ok. 5 miesięcy. Znaczna różnica pomiędzy podgrupą pierwszą i czwartą wynika głównie z selekcji chorych do poszczególnych schematów i wpływu czynników prognostycznych na przeżycia. Wobec powyższego porównywanie tych dwóch podgrup pod względem zastosowanego schematu nie ma sensu.

Natomiast na uwagę zasługują wyniki uzyskane w podgrupie 2 i 3, w których po zastosowaniu radioterapii hypofrakcjonowanej podwyższano dawkę całkowitą przy pomocy boostu radiochirurgicznego. Mediany czasów przeżycia w tych grupach wynosiły 7-8 miesięcy, a po przeprowadzeniu analizy wieloczynnikowej nie wykazano istotnej statystycznie różnicy w porównaniu z podgrupą chorych leczonych konwencjonalnie. Wyniki sugerują, że u chorych, u których nie ma możliwości leczenia radykalnego, zastosowanie radioterapii paliatywnej z podwyższeniem dawki przy pomocy SRS pozwala na uzyskanie wyników zbliżonych do uzyskanych konwencjonalną radioterapią przy krótkim czasie leczenia.

Brak różnicy pomiędzy schematem 2 i 3 wynika prawdopodobnie z niewielkiej różnicy dawek całkowitych, wynoszących jedynie $8 \mathrm{~Gy}$.

\section{Dawka promieniowania stosowana w radiochirurgii}

Dawka promieniowania jonizującego stosowana w radiochirurgii w podgrupach 2 i 3 mieściła się w przedziale 5-15 Gy (mediana 8). W analizie jednoczynnikowej wykazano znamienny statystycznie wpływ wielkości dawki na długość przeżycia $(p=0,02)$. Mediany i średnie czasów przeżycia wynosiły 6,4 i 7,5 oraz 8,9 i 11,2 odpowiednio dla chorych napromienianych dawką poniżej 8 Gy i powyżej $8 \mathrm{~Gy}$. Uzyskane wyniki wydają się być logiczne i potwierdza- 
ją wpływ wielkości dawki całkowitej na wydłużenie czasów przeżycia. W tym przypadku należy jednak pamiętać o kilku czynnikach mających kluczowy wpływ na uzyskiwane wyniki. Głównym z nich są kryteria kwalifikacji do leczenia radiochirurgicznego. Wielkość dawki jest ściśle uzależniona od lokalizacji oraz objętości guza. O ile lokalizacja w tym przypadku pozostaje bez znaczenia, to objętość guza oraz stopień miejscowego zaawansowania miały znamienny statystycznie wpływ na przeżycia całkowite zarówno w analizie jednoczynnikowej, jak i w analizie wieloczynnikowej.

Biorąc pod uwagę powyższe, chorzy de facto rokujący lepiej poddawani byli radioterapii wyższą dawką w porównaniu z chorymi z bardziej rozległymi guzami. Uzyskane wyniki są więc nie tylko związane z wielkością dawki całkowitej, ale również z zaawansowaniem miejscowym choroby.

\section{Leczenie ratujace}

Zastosowanie leczenia ratującego u chorych na glejaki wielopostaciowe jest tematem kontrowersyjnym i trudnym. Przedstawiane wyniki mają charakter retrospektywnych analiz. Kolejny problem jest związany z preselekcją chorych i w związku z tym z trudnościami w interpretacji wyników. Badania wskazują na korzyść z zastosowania takiego leczenia u chorych w stanie klinicznym umożliwiającym jego przeprowadzenie [57,58]. Do najczęściej opisywanych metod należą reoperacja, ponowne napromienianie oraz zastosowanie paliatywnej chemioterapii.

Zastosowanie radiochirurgii w leczeniu chorych z guzami mózgu jest obecnie powszechne. Zastosowanie radiochirurgii w leczeniu ratującym pośród chorych leczonych konwencjonalnie pozwala na uzyskanie median czasów przeżycia od zastosowanej SRS w przedziale około 7-10 miesięcy i median od diagnozy w przedziale 17-22 miesięcy [59-63]. Należy podkreślić jednak, iż opisywane wyniki dotyczą badań w małych grupach chorych.

$\mathrm{U}$ chorych leczonych paliatywnie rola tej metody nie jest jednak obecnie sprecyzowana. W niniejszej rozprawie rozpatrywano dwa aspekty stosowania radiochirurgii u chorych leczonych paliatywnie. Pierwszy to zastosowanie boostu SRS jako część leczenia pierwotnego, co zostało opisane powyżej, drugi - to wykorzystanie radiochirurgii w radioterapii paliatywnej kolejnego rzutu.

W badanym materiale własnym uzyskano znamienną statystycznie różnicę w medianach przeżyć u chorych, u których zastosowano leczenie ratujące oraz u których takiego leczenia nie zastosowano (mediany odpowiednio 10,5 vs 5). Z uwagi jednak na fakt, iż do leczenia ratującego dobierano chorych do niego się kwalifikujących (dobry stan ogólny, a w przypadku chorych leczonych z zastosowaniem radiochirurgii guz do $4 \mathrm{~cm}$ i maksymalnie trzy ogniska w przypadku wieloogniskowości), a nie stosowano go u chorych w złym stanie ogólnym, rokujących znacznie gorzej, jak również ze względu na brak grupy kontrolnej uzyskane w ten sposób wyniki okazały się trudne w interpretacji.

W związku z powyższym chorych podzielono na podgrupy z uwzględnieniem schematu zastosowanej radioterapii oraz rodzaju zastosowanego leczenia ratującego.

Biorąc pod uwagę fakt, iż chorzy, u których zastosowano SRS bądź inne leczenie ratujące (ale bez SRS), byli chorymi w podobnym wieku i stanie ogólnym, grupy te można porównać.

W podgrupie 2 mediany czasów przeżycia wynosiły odpowiednio 14,5, 9 i 5 miesięcy dla chorych, u których zastosowano radiochirurgię $w$ leczeniu ratującym, u których radiochirurgii nie zastosowano oraz u których nie stosowano żadnego leczenia ratującego $(p=0,0001)$. W podgrupie 3 mediany wynosiły odpowiednio $10,5,8,7$ oraz 5,2 ( $p=0,0008)$, w podgrupie 4 odpowiednio 9,5, 4,7 oraz 4 miesiące $(p=0,02)$.

Uzyskano znacznie większe mediany czasów przeżycia u chorych, u których zastosowano radiochirurgię w porównaniu z chorymi, u których jej nie stosowano oraz u których w ogóle nie stosowano leczenia ratującego.

W analizie wieloczynnikowej wykazano, iż leczenie ratujące wiąże się z obniżeniem względnego ryzyka zgonu (HR-0,5, p = 0,003), a w przypadku zastosowania SRS wyniki są jeszcze lepsze (HR-0,37, $p=0,000001)$.

Biorąc powyższe pod uwagę, nasuwa się wniosek, iż zastosowanie radiochirurgii $\mathrm{w}$ leczeniu ratującym powoduje wydłużenie przeżyć całkowitych w grupie chorych w dobrym stanie ogólnym (Zubrod 0-2) oraz spełniających powszechnie stosowane kryteria kwalifikacji do radiochirurgii.

\section{Tolerancja leczenia}

Uzyskane wyniki potwierdzają fakt, iż radioterapia guzów mózgu jest bezpieczna i dobrze tolerowana. Toksyczność wczesna leczenia pozostaje na niskim poziomie $(17,5 \%)$, a występujące objawy są dobrze kontrolowane z zastosowaniem odpowiednich leków. Zła tolerancja leczenia, powodująca konieczność jego przerwania lub zakończenia, dotyczyła jedynie dziewięciu chorych, co stanowiło zaledwie 4\%. Otrzymane wyniki są zbliżone do opisywanych w piśmiennictwie [64-66].

\section{Wnioski}

Uzyskane wyniki pozwalają na sformułowanie następujących wniosków:

- Wiek poniżej 40 lat, dobry stan ogólny (Zubrod 0-2), pojedynczy guz o objętości do $30 \mathrm{~cm}^{3}$ i zastosowanie cytoredukcyjnej operacji są niezależnymi pozytywnymi czynnikami prognostycznymi przeżycia.

- Zastosowanie boostu radiochirurgicznego jako elementu pierwotnego leczenia w radioterapii paliatywnej lub jako leczenia kolejnego rzutu u chorych w dobrym stanie ogólnym i z guzami o małych objętościach pozwa- 
la na wydłużenie przeżyć całkowitych w porównaniu z chorymi, u których stosowano inny rodzaj leczenia ratującego lub nie stosowano go wcale.

- Dobra iakceptowalna tolerancja leczenia porównywalna dla każdego z zastosowanych schematów radioterapii.

\section{Konflikt interesów: nie zgłoszono}

\section{Dr n. med. Grzegorz Głowacki}

Centrum Onkologii — Instytut im. Marii Skłodowskiej-Curie

Oddział w Gliwicach, Zakład Radioterapii

e-mail:geno@poczta.onet.pl

Otrzymano: 27 lutego $2016 \mathrm{r}$.

Przyjęto do druku: 23 marca 2016 r.

\section{Piśmiennictwo}

1. Gliński B, Dymek P, Skołyszewski J. Altered therapy schedule in postoperative treatment of patients with malignant gliomas. Twenty year experience of the Maria Skłodowska-Curie Memorial Center In Kraków, 1973-1993. J Neurooncol 1998; 36: 159-165.

2. Curran W, Scott C, Horton J i wsp. Recursive partitioning analysis of prognostic factors in three Radiation Therapy Oncology Group malignant glioma trials. J Nat/ Cancer Inst 1993; 85: 704-710.

3. Gliński B. Postoperative hypofractionated radiotherapy versus conventionally fractionated radiotherapy in malignant gliomas. A preliminary report on a randomized trial. J Neurooncol 1993; 16: 167-172.

4. Gundersen S, Lote K, Hannisdal E. Prognostic factors for glioblastoma multiforme: development of a prognostic index. Acta Oncol 1996; 35 Suppl 8: 123-127.

5. Hulshof M, Koot R, Schimmel E i wsp. Prognostic factors in glioblastoma multiforme. 10 years experience of a single institution. Strahlenther Onkol 2001; 177: 283-90.

6. Lamborn K, Chang S, Prados MD i wsp. Prognostic factors for survival of patients with glioblastoma: recursive partitioning analysis. Neuro Oncol 2004; 6: 227-235.

7. Li SW, Qiu XG, Chen BS i wsp. Prognostic factors influencing clinical outcomes of glioblastoma multiforme. Chin Med J 2009; 122: 1245-1249.

8. Lamborn K, Chang S, Prados M. Prognostic factors for survival of patients with glioblastoma: Recursive partitioning analysis. Neuro Oncol 2004; 6: 227-235.

9. Holick C, Giovannucci E, Rosner B i wsp. Prospective study of cigarette smoking and adult glioma: dosage, duration, and latency. Neuro Oncol 2007; 9: 326-334.

10. Odrazka K, Petera J, Kohlova T i wsp. Prognostic impact of hemoglobin level prior to radiotherapy on survival in patients with glioblastoma. Strahlenther Onkol 2003; 179: 615-619.

11. Lally BE, Colasanto JM, Fischer JJ i wsp. Is there an optimal hemoglobin level for patients with glioblastoma multiforme? Cancer J 2004; 10: 391-396.

12. Simpson J, Horton J, Scott C i wsp. Influence of location and extent of surgical resection on survival of patients with glioblastoma multiforme: results of three consecutive Radiation Therapy Oncology Group (RTOG) clinical trials. Int J Radiat Oncol Biol Phys 1993; 26: 239-244.

13. Jeremic B, Grujicic D, Antunovic V i wsp. Influence of extent of surgery and tumour location on treatment outcome of patients with glioblastoma multiforme treated with combined modality approach. J Neurooncol 1994; 21: 177-185.

14. Carson K, Grossman S, Fisher J. Prognostic factors for survival in adult patients with recurrent glioma enrolled onto the new approaches to brain tumour therapy CNS consortium phase I and II clinical trials. J Clin Oncol 2007; 25: 2601-2606.

15. Li SW, Qiu XG, Chen BS. Prognostic factors influencing clinical outcomes of glioblastoma multiforme. Chin Med J 2009; 122: 1245-1249.

16. Klautke G, Schütze M, Bombor I. Concurrent chemoradiotherapy and adjuvant chemotherapy with Topotecan for patients with glioblastoma multiforme. J Neurooncol 2006; 77: 199-205.

17. Walid MS. Prognostic factors for long-term survival after Glioblastoma. Perm J 2008; 12: 45-48.

18. Coffey R, Lunsford L, Taylor F. Survival after stereotactic biopsy of malignant gliomas. Neurosurgery 1988; 22: 465-473.
19. Ushio Y, Kochi M, Hamada J i wsp. Effect of surgical removal on survival and quality of life in patients with supratentorial glioblastoma. Neurol Med Chir 2005; 45: 454-461.

20. Pope W, Sayre J, Perlina A i wsp. MR imaging correlates of survival in patients with high-grade gliomas. AJNR Am J Neuroradiol 2005; 26: 2466-74.

21. Ammirati $M$, Vick N, Liao $Y$ i wsp. Effect of the extent of surgical resection on survival and quality of life in patients with supratentorial glioblastomas and anaplastic astrocytomas. Neurosurgery 1987; 21: 201-206.

22. Lacroix M, Abi-Said D, Fourney D i wsp. A multivariate analysis of 416 patients with glioblastoma multiforme: prognosis, extent of resection, and survival. J Neurosurg 2001; 95: 190-198.

23. Keles $G$, Anderson B, Berger M. The effect of extent of resection on time to tumour progression and survival in patients with glioblastoma multiforme of the cerebral hemisphere. Surg Neurol 1999; 52: 371-379.

24. Sanai N, Berger MS. Glioma extent of resection and its impact on patient outcome. Neurosurgery 2008; 62: 753-764.

25. Buckner J, Schomberg P, McGinnis W i wsp. A phase III study of radiation therapy plus carmustine with or without recombinant interferon-alpha in the treatment of patients with newly diagnosed high-grade glioma. Cancer 2001; 92: 420-433.

26. Brown $\mathrm{P}$, Maurer M, Rummans T i wsp. A prospective study of quality of life in adults with newly diagnosed high-grade gliomas: the impact of the extent of resection on quality of life and survival. Neurosurgery 2005; 57: 495-504.

27. Stark A, Nabavi A, Mehdorn H i wsp. Glioblastoma multiforme-report of 267 cases treated at a single institution. Surg Neurol 2005; 63: 162-169.

28. Walker M, Green S, Byar D i wsp. Randomized comparisons of radiotherapy and nitrosoureas for the treatment of malignant glioma after surgery. N Engl J Med 1980; 303: 1323-1329.

29. Walker M. Alexander E, Hunt W i wsp. Evaluation of BCNU and/or radiotherapy in the treatment of anaplastic gliomas. A cooperative clinical trial. J Neurosurg 1978; 49: 333-343.

30. Andersen A. Postoperative irradiation of glioblastomas. Results in a randomized series. Acta Radiol Oncol Radiat Phys Biol 1978; 17:475-484.

31. Kristiansen K, Hagen S, Kollevold T i wsp. Combined modality therapy of operated astrocytomas grade III and IV. Confirmation of the value of postoperative irradiation and lack of potentiation of bleomycin on survival time: a prospective multicenter trial of the Scandinavian Glioblastoma Study Group. Cancer 1981; 47: 649-652.

32. Walker M, Strike T, Sheline G. An analysis of dose-effect relationship in the radiotherapy of malignant gliomas. Int J Radiat Oncol Biol Phys 1979; 5: 1725-1731.

33. Salazar O, Rubin P, Feldstein M i wsp. High dose radiation therapy in the treatment of malignant gliomas: final report. Int J Radiat Oncol Biol Phys 1979; 5: 1733-1740.

34. Chang C, Horton J, Schoenfeld D i wsp. Comparison of postoperative radiotherapy and combined postoperative radiotherapy and chemotherapy in the multidisciplinary management of malignant gliomas. A joint Radiation Therapy Oncology Group and Eastern Cooperative Oncology Group study. Cancer 1983; 52: 997-1007.

35. Bleehen N, Stenning S. A Medical Research Council trial of two radiotherapy doses in the treatment of grades 3 and 4 astrocytoma. The Medical Research Council Brain Tumour Working Party. Br J Cancer 1991; 64: 769-774.

36. Muacevic A, Kreth F. Quality-adjusted survival after tumour resection and/or radiation therapy for elderly patients with glioblastoma multiforme. J Neurol 2003; 250: 561-568.

37. Phillips C, Guiney M, Smith J i wsp. A randomized trial comparing 35 Gy in ten fractions with $60 \mathrm{~Gy}$ in 30 fractions of cerebral irradiation for glioblastoma multiforme and older patients with anaplastic astrocytoma. Radiother Oncol 2003; 68: 23-26.

38. Roa W, Brasher P, Bauman G i wsp. Abbreviated course of radiation therapy in older patients with glioblastoma multiforme: a prospective randomized clinical trial. J Clin Oncol 2004; 22: 1583-1588.

39. Souhami L, Seiferheld W, Brachman D i wsp. Randomized comparison of stereotactic radiosurgery followed by conventional radiotherapy with carmustine to conventional radiotherapy with carmustine for patients with glioblastoma multiforme: report of Radiation Therapy Oncology Group 93-05 protocol. Int J Radiat Oncol Biol Phys 2004; 60: 853-860.

40. Chang C, Horton J i wsp. Comparison of postoperative radiotherapy and combined postoperative radiotherapy and chemiotherapy in the multidisciplinary management of malignant gliomas. A joint Radiation Therapy Oncology Group and Eastern Cooperative Oncology Group study. Cancer 1983; 52: 997-1007. 
41. Nelson D, Diener-West $M$, Horton J i wsp. Combined modality approach to treatment of malignant gliomas-re-evaluation of RTOG 7401/ECOG 1374 with long-term follow-up: a joint study of the Radiation Therapy Oncology Group and the Eastern Cooperative Oncology Group. NCI Monogr 1988; 6: 279-284.

42. Douglas J, Stelzer K, Mankoff D i wsp. [F-18]-fluorodeoxyglucose positron emission tomography for targeting radiation dose escalation for patients with glioblastoma multiforme: clinical outcomes and patterns of failure. Int J Radiat Oncol Biol Phys 2006; 64: 886-891.

43. Scott C, Curran W i wsp. Long term results of RTOG 90-06. A randomized trial of hyperfractionated radiotherapy to $72 \mathrm{~Gy}$ and carmustine vs standard RT and carmustine for malignant glioma patients with emphasis on anaplastic astrocytoma patients. JClin Oncol 1998; 17:401.

44. Cardinale R, Won M, Choucair A i wsp. A phase II trial of accelerated radiotherapy using weekly stereotactic conformal boost for supratentorial glioblastoma multiforme: RTOG 0023. Int J Radiat Oncol Biol Phys 2006; 65: 1422-1428.

45. Selker R, Shapiro W, Burger P i wsp. The Brain Tumour Cooperative Group NIHTrial 87-01: a randomized comparison of surgery, external radiotherapy, and carmustine versus surgery, interstitial radiotherapy boost, external radiation therapy, and carmustine. Neurosurgery 2002; 51: 343-355.

46. Werner-Wasik M, Scott C, Nelson D i wsp. Final report of a phase I/II trial of hyperfractionated and accelerated hyperfractionated radiation therapy with carmustine for adults with supratentorial malignant gliomas. Radiation Therapy Oncology Group Study 83-02. Cancer 1996; 77: 1535-1543.

47. Deutsch M, Green S, Strike T i wsp. Results of a randomized trial comparing $\mathrm{BCNU}$ plus radiotherapy, streptozotocin plus radiotherapy, $\mathrm{BCNU}$ plus hyperfractionated radiotherapy, and $\mathrm{BCNU}$ following misonidazole plus radiotherapy in the postoperative treatment of malignant glioma. Int J Radiat Oncol Biol Phys 1989; 16: 1389-1396.

48. Payne D, Simpson W, Keen C i wsp. Malignant astrocytoma: hyperfractionated and standard radiotherapy with chemotherapy in a randomized prospective clinical trial. Cancer 1982; 50: 2301-2306.

49. Prados M, Wara W, Sneed PK i wsp. Phase III trial of accelerated hyperfractionation with or without difluoromethylornithine (DFMO) versus standard fractionated radiotherapy with or without DFMO for newly diagnosed patients with glioblastoma multiforme. Int J Radiat Oncol Biol Phys 2001; 49: 71-77.

50. Shrieve D, Alexander E 3rd, Wen P i wsp. Comparison of stereotactic radiosurgery and brachytherapy in the treatment of recurrent glioblastoma multiforme. Neurosurgery 1995; 36: 275-282.
51. Sanghavi S, Skrupy R, Badic B i wsp. Recurrent malignant gliomas treated with radiosurgery. J Radiosurg 1999; 2: 119-125.

52. Park J, Suh J, Barnett G i wsp. Survival after stereotactic radiosurgery for recurrent glioblastoma multiforme. J Radiosurg 2000; 3: 169-175.

53. Combs S, Widmer V, Thilmann Ci wsp. Stereotactic radiosurgery (SRS) treatment option for recurrent glioblastoma multiforme (GBM). Cancer 2005; 104: 2168-2173.

54. Walker M, Strike T, Sheline G. An analysis of dose-effect relationship in the radiotherapy of malignant gliomas. Int J Radiat Oncol Biol Phys 1979; 5: 1725-1731.

55. Bauman G, Gaspar L, Fisher B i wsp. A prospective study of short-course radiotherapy in poor prognosis glioblastoma multiforme. Int J Radiat Oncol Biol Phys 1994; 29: 835-839.

56. McAleesea J, Stenning S, Ashley Si wsp. Hypofractionated radiotherapy for poor prognosis malignant glioma: matched pair survival analysis with MRC controls. Radiother Oncol 2003; 67: 177-182.

57. Hau P, Baumgart U, Pfeifer K i wsp. Salvage therapy in patients with glioblastoma: is there any benefit? Cancer 2003; 98: 2678-86.

58. Mandl ES, Dirven CM, Buis DR i wsp. Repeated surgery for glioblastoma multiforme: only in combination with other salvage therapy. Surg Neurol 2008; 69: 506-509.

59. Biswas $T$, Okunieff $P$, Schell M i wsp. Stereotactic radiosurgery for glioblastoma: retrospective analysis. Radiat Oncol 2009; 4: 11.

60. Park J, Suh J, Barnett G. Survival after stereotactic radiosurgery for recurrent glioblastoma multiforme. J Radiosurg 2000; 3: 169-175.

61. Villavicencio A, Burneikienè, Romanelli P i wsp. Survival following stereotactic radiosurgery for newly diagnosed and recurrent glioblastoma multiforme: a multicenter experience. Neurosurg Rev 2009;32:417-424.

62. Patel $M$, Siddiqui $F$, Jin J i wsp. Salvage reirradiation for recurrent glioblastoma with radiosurgery: radiographic response and improved survival. J Neurooncol 2009; 92: 185-191.

63. Combs S, Widmer V, Thilmann C i wsp. Stereotactic radiosurgery (SRS): treatment option for recurrent glioblastoma multiforme (GBM). Cancer 2005; 104: 2168-2173.

64. Hoppe RT, Philips TL, Roach M (red.). Leibel and Phillips textbook of radiation oncology. Philadelphia: Elsevier Saunders, 2010.

65. Gunderson L, Tepper J (red.). Clinical radiation oncology. $2^{\text {nd }}$ ed. Philadelphia: Elsevier, Churchill Livingstone, 2007: 457-515.

66. McKenzie M, Souhami L, Caron J i wsp. Early and late complications following dynamic stereotactic radiosurgery and fractionated stereotactic radiotherapy. Can J Neurol Sci 1993; 20: 279-285. 